\title{
Habitat structure, dispersal strategies and queen number in two boreal Leptothorax ants
}

\author{
Jürgen Heinze \\ Theodor-Boveri-Institut, Biozentrum der Universität, LS Verhaltensphysiologie und Soziobiologie, \\ Am Hubland, D-97074 Würzburg, Germany \\ Received: 15 March 1993/Accepted: 12 July 1993
}

\begin{abstract}
In two nearctic ants, Leptothorax canadensis and Leptothorax sp. A, young queens may either found their own nest solitarily after mating or seek adoption into an established colony. Whether a queen disperses or not is associated with genetically determined queen morphology in Leptothorax sp. A. Whereas a majority of winged queens attempt solitary colony founding after mating, most wingless, intermorphic queens return to their maternal nests and new colonies are founded by budding after hibernation. The latter strategy appears to be correlated with patchy, isolated habitats, whereas in extended boreal forests dispersal on the wing is probably more common. Alternative dispersal strategies strongly affect the average number of queens per colony and seasonal fluctuations of colony structure.
\end{abstract}

Key words: Formicidae - Leptothorax - Queen polymorphism - Wing reduction - Colony founding

Adult pterygote insects are characterized by one or two pairs of wings. Nevertheless, wingless forms have repeatedly evolved in many orders, including flies, moths, and beetles. Species in which fully winged and wingreduced adults co-occur are helpful tools for the analysis of dispersal strategies (e.g., Roff 1980; Roff and Fairbairn 1991; Wagner and Liebherr 1992). Numerous studies have therefore focused on the physiological causes and the life history consequences of wing reduction in wing-dimorphic insects (e.g., Varvio-Aho et al. 1978; Zera and Rankin 1989; Aukema 1991).

Wing dimorphism in social insects, especially ants, is less well understood. Although wingless individuals workers and dealate queens - predominate in ant societies, male and female sexuals of most species bear wings when eclosing and mate during a swarming flight. Alternative ground-bound mating strategies are known from several species, including social parasites, army ants, tramp species, and species with small colony size (Hölldobler and Bartz 1985; Hölldobler and Wilson
1990; Peeters 1991), and in some of these species, wingless sexuals have evolved.

Wing reduction in female sexuals is generally thought to be correlated with a shift of colony founding strategies from independent founding to colony fission or budding (Bolton 1986; Villet 1989; Tinaut and Heinze 1992; Buschinger and Heinze 1992; Heinze et al. 1992a; but see Villet 1991). However, empirical data on the ecological and sociobiological significance of wing reduction in ant queens are sparse and hypotheses are based on limited, casual observations (e.g., Briese 1983). Two sympatric species of Leptothorax (s.str.) in North America provide an ideal system to study the effects of wing reduction in ant queens on population and colony parameters, as well as the role of ecology in selecting for winglessness.

Queens of Leptothorax cf. canadensis are uniformly winged when eclosing, but in Leptothorax sp. A winged (gynomorphic) and wingless (intermorphic) queens cooccur (Heinze and Buschinger 1987). According to the results of cross-breeding studies, queen morph is genetically mediated, probably by a diallelic locus (or a group of closely linked loci): a dominant allele impairs the development of wings, ocelli and thoracic sclerites in female sexual larvae (Heinze and Buschinger 1989). Preliminary field observations indicated a correlation between queen morphology and type of habitat in Leptothorax sp. A (Heinze and Buschinger 1988a; Heinze 1989a).

The aim of this paper is to compare the life histories of Leptothorax canadensis and Leptothorax sp. A and to demonstrate how queen morphology, dispersal strategy, habitat structure, and colony organization are interrelated.

\section{Material and methods}

The two species studied, Leptothorax (s.str.) sp. A and L. (s.str.) ef. canadensis (also referred to as Leptothorax sp. B, Heinze 1989b), belong to a cluster of morphologically very similar species in North America, most of which have not yet been formally described. Some taxa, including the two species of this study, were recently characterized by karyotype and allozyme patterns (Heinze and Buschinger 
1988b; Heinze 1989b; Loiselle et al. 1990). A description of Leptothorax sp. A is being prepared by André Francoeur (Université de Québec à Chicoutimi).

Complete Leptothorax colonies were collected at various sites in New England and eastern Canada and immediately censused after return to the laboratory. Due to early snow and wildfires not all seasonal collections could be made in the same populations, Colonies were kept in the laboratory according to techniques developed by Buschinger (1974). Dissections were carried out as described by Buschinger and Alloway (1978).

The distribution of nests was mapped at two sites in Tadoussac and in one site each in Rouyn-Noranda and at Lac Arthabaska. Nest distances were measured with a tape-measure, using trees as reference points, but only roughly estimated at Lac Arthabaska. Not all dense spruce or alder thickets were thoroughly searched for ant nests, hence it is likely that at least some $L$. canadensis colonies were missed.

The significance of differences between frequency distributions of demographic data was tested using the Kolmogorov-Smirnov two-sample test (KS-test) and the Mann-Whitney $U$-test (Sokal and Rohlf 1981; Sachs 1992).

The complex division of reproduction in some leptothoracine ants calls for a strict definition of terms. Both a purely functional and morphological definition of the term "queen" require specifying adjectives for the various types of potential or actual reproductives. I here use "queens" for all female reproductives, which are inseminated, and "virgin queens" for uninseminated females with spermatheca, regardless of external morphology. Peeters (1991) suggested referring to wingless female reproductives of leptothoracines as "reproductive intercastes", defining intercastes as "hybrid phenotypes" with the uncoordinated expression of queen and worker characteristics. Though wingless female reproductives of Leptothorax sp. A may vary considerably in their external morphology, they are clearly distinct from typical workers (e.g., in the possession of a fully developed ovary with six ovarioles and a spermatheca, and the presence of a promesonotal suture, Heinze and Buschinger 1987). They are reared predictably and regularly in some colonies, but never in others. As in Harpagoxenus sublaevis (e.g., Buschinger 1978), single-pair crosses suggest genetic mechanisms which affect larval development in a well-ordered way. I therefore use the term "intermorphic" to describe the morphology of wingless queens of Leptothorax sp. A. Queens with a fully developed thoracic skeleton are called "gynomorphic" (see also Buschinger and Winter 1976; Francoeur et al. 1985; Loiselle and Francoeur 1988).

\section{Results}

\section{Nest site and habitat preferences}

Leptothorax sp. A and L. canadensis are common ants throughout boreal biomes in northeastern North America and may locally reach densities of four nests and more per square meter. Leptothorax sp. A is more limited in the type of nest sites used than L. canadensis. In Québec, its nests were found in rotting pine branches and occasionally under stones in partly shaded areas, such as light patches in boreal coniferous forests (e.g., Lac Arthabaska in Grands Jardins Park, St. Siméon) or on sparsely overgrown rocky hillocks (e.g., Tadoussac, Matagami). L. canadensis, on the other hand, occurred both in areas exposed to the sun and in shaded areas in coniferous forests, and was occasionally collected in spruce bogs, dense spruce forests, and deciduous forests with maples, oaks, and white pines (e.g. near Milton, Ontario). In areas from which Leptothorax sp. A was absent, L. canadensis also colonized partly shaded sites. L. canadensis nested in decaying pine branches, but also in dead, upright alder twigs, under moss or flat stones, and in the hollow stems of annual plants. Ants which occasionally compete with Leptothorax (s.str.) for nest sites, e.g. Camponotus herculeanus, Myrmica alaskensis, Tapinoma sessile and others, appeared similarly abundant in all studied populations. The facultatively polygynous L. (s.str.) retractus occurred in high densities in RouynNoranda, where it apparently displaced $L$. canadensis from the fully shaded areas, but was absent or only sporadically found in other sites.

\section{Intermorphic queens in the field}

All female reproductives (appr. 700) of L. canadensis examined were gynomorphic, i.e., in this species not a
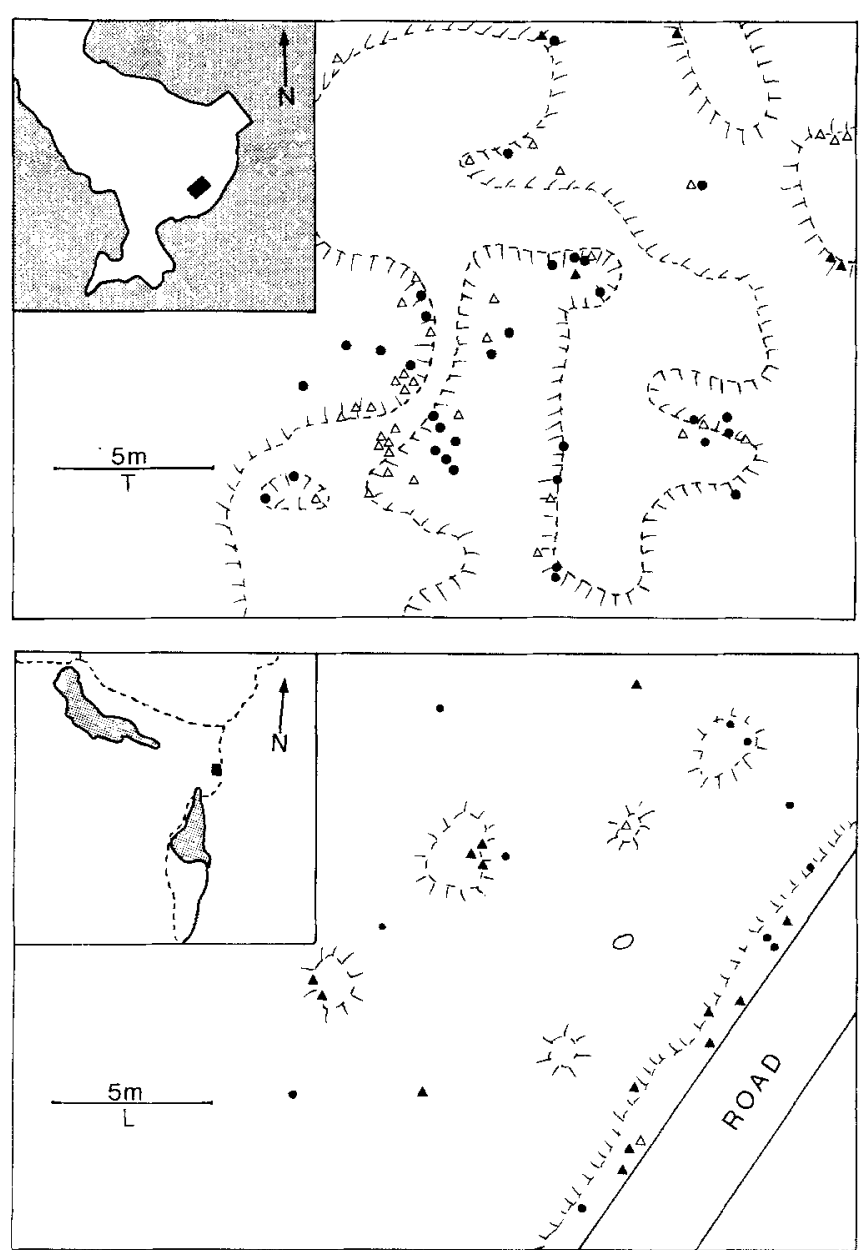

Fig. 1. Distribution of nests of Leptothorax sp. A with intermorphic and gynomorphic queens (white and black triangles respectively) and of L. canadensis (black circles) in two populations in Québec. The population in Tadoussac $(T)$ is wind-exposed and nests are found in insular groups on rocky outcrops surrounded by denser forests. The population near Lac Arthabaska in Grand Jardins Park $(L)$ is extended and colonies are found isolated or in small groups in a light forest. Hatched areas indicate the edge of the denser forests, which extend away from the dotted line. Most colonies of Leptothorax sp. A are located near the forest edge in Tadoussac. The small inset indicates the geographical situation of the collecting sites (black). The sea (in Tadoussac) and lakes (in Lac Arthabaska) are indicated by dotted areas 
Table 1. Frequency of colonies of Leptothorax sp. A containing gynomorphic queens in various populations in Québec and New England

\begin{tabular}{llll}
\hline Population & $\begin{array}{l}\text { Collection } \\
\text { date }\end{array}$ & Colonies & \\
\cline { 3 - 4 } & Total & $\frac{\text { With gynomorphic queens }}{n}$ & $(\%)$
\end{tabular}

Isolated, wind-exposed habitat patches

Tadoussac, Québec 1983 (Co. Saguenay) 1985

$\begin{array}{rrrr}1987 & 44 & 8 & 18\end{array}$

$\begin{array}{llll}1988 & 139 & 31 & 22\end{array}$

$\begin{array}{rrrr}1989 & 28 & 8 & 29\end{array}$

1991

total

Matagami, Québec

1987

\begin{tabular}{rrr}
48 & 16 & 33 \\
\hline 368 & 85 & 23
\end{tabular}

(Terr. Abitibi)

La Baie, Québec

(Co. Chicoutimi)

1983

$1985 \mathrm{a}$

$1985 b$

total

\begin{tabular}{rrr}
14 & 1 & 7 \\
14 & 4 & 29 \\
11 & 2 & 18 \\
6 & 6 & 100 \\
\hline 31 & 12 & 39
\end{tabular}

Extended habitats

St. Siméon, Québec

(Co. Charlevoix-Est)

\begin{tabular}{lrrr}
1983 & 24 & 13 & 54 \\
1988 & 17 & 10 & 59 \\
1991 & 16 & 7 & 44 \\
\cline { 2 - 4 } total & 57 & 30 & 53 \\
1988 & 28 & 25 & 89 \\
& & & \\
1987 & 7 & 5 & 71 \\
1990 & 46 & 39 & 85 \\
total & 53 & 44 & 83 \\
1990 & 8 & 8 & 100 \\
& & & \\
1988 & 27 & 26 & 96 \\
1989 & 12 & 12 & 100 \\
1991 & 9 & 9 & 100 \\
total & 48 & 47 & 98
\end{tabular}

Grands Jardins ${ }^{\mathrm{a}}$, Québec

(Co. Charlevoix-Est)

Rouyn-Noranda, Québec

(Co. Témiscamingué)

Arntfield, Québec

(Co. Témiscamingué)

Mt. Monadnock, N.H.

(Cheshire Co.)

48

47

The occurrence of gynomorphic queens appears to be associated with homogenous habitats (two-tailed $U$-test, $U=0, U_{0.0513,5]}=0 ; P=0.05$ ). It is unclear why all of the colonies collected in La Baie (1985b) had gynomorphic queens. Probably the habitat, a rocky outcrop surrounded by dense forest, was only recently colonized

${ }^{a}$ Lac Arthabaska and Mt. du Lac des Cygnes single intermorphic queen was found. In contrast, intermorphic queens occurred regularly throughout most studied populations of Leptothorax sp. A. The frequency of intermorphic queens differed from site to site but was rather constant within populations over time (Table 1). Intermorphic queens were more common in isolated habitat patches, such as the rocky peninsula Pointe de l'Islet in Tadoussac, while gynomorphic queens predominated in extended, uniform habitats, such as light pine forests (St. Siméon, Lac Arthabaska), shrub forests (Mt. Monadnock), or mountain tundra (Mt. du Lac des Cygnes). Nest density was higher in Tadoussac than in St. Siméon or near Lac Arthabaska. However, in the latter two habitats nests appeared to be more homogeneously scattered over large areas, with nest clusters mainly along man-made clearings and forest roads (Fig. 1).

\section{Colony demography: queen numbers}

Colonies of both species may contain multiple inseminated queens. In L. canadensis, approximately $30-40 \%$ of all colonies were polygynous, i.e, had several inseminated, egg-laying queens. The frequency of polygynous nests appeared to be independent of population and season (Table 2).

The frequency of multiple-queen colonies of Leptothorax sp. A, however, varied strongly between populations and seasons. In populations with a large proportion of intermorphic queens (e.g., Tadoussac), 33\% of all nests (81 of 241) had several inseminated intermorphs, but in populations with predominantly gynomorphic queens (Rouyn-Noranda, Lac Arthabaska, Mt. Monadnock), multiple inseminated gynomorphs were only present in $11 \%$ of colonies (17 of 157) (difference of frequency distributions was tested with the KS-test, $P<0.001$ ). 
Table 2. Percentage of $L$. canadensis colonies with multiple queens in various populations in Québec, Ontario, and New England

\begin{tabular}{lll}
\hline Population & Colonies & Colonies with $>1$ queen \\
$n$ & $n$ & $n$
\end{tabular}

\section{Summer}

Mt. du Lac des Cygnes,
Tadoussac, Qué.
19

9

Qué.

Mt. Monadnock,. N.H.

Milton, Ont.

\section{9}

5

47

56

Winter

Tadoussac, Qué.

Mt. du Lac des Cygnes,

Qué.

Mt. Monadnock, N.H.

Mt. Washington, N.H.

$\begin{array}{rrr}9 & 4 & 44 \\ 16 & 4 & 25\end{array}$

$28 \quad 12 \quad 43$

$25 \quad 11 \quad 44$

$\begin{array}{lll}75 & 28 & 37\end{array}$

18

7
Not all female reproductives were dissected; however, dissection results with a random sample of nests showed that most were inseminated and laid eggs

The frequency of polygynous nests was not different between winter and summer samples (two-tailed $U$-test, $U=8.5 ; U_{0.1[4,4]}=1$; $P>0.1)$

Table 3. Frequency of multiple-queen colonies of Leptothorax sp. $A$ in different seasons and habitats

\begin{tabular}{|c|c|c|c|c|c|c|c|}
\hline \multicolumn{2}{|l|}{$\begin{array}{l}\text { Collecting } \\
\text { site and season }\end{array}$} & \multirow{2}{*}{$\begin{array}{l}\begin{array}{l}\text { no } \\
\text { queen }\end{array} \\
6\end{array}$} & \multirow{2}{*}{$\frac{19}{21}$} & \multirow{2}{*}{$\begin{array}{c}\text { I웅 } \\
4\end{array}$} & \multirow{2}{*}{$\frac{\mathrm{G}_{+}}{5}$} & \multirow{2}{*}{$\begin{array}{c}\text { GOQ } \\
-\end{array}$} & \multirow{2}{*}{$\begin{array}{l}\text { IGqo } \\
-\end{array}$} \\
\hline Tadoussac & S 83 & & & & & & \\
\hline & S 85 & 23 & 45 & 11 & 10 & - & 2 \\
\hline & S 87 & 10 & 33 & 3 & 3 & 1 & 3 \\
\hline & S 88 & 15 & 53 & 21 & 15 & 6 & 1 \\
\hline \multirow[t]{3}{*}{ Total } & & 54 & 218 & 39 & 33 & 7 & 6 \\
\hline & & & & $15 \%$ & & $17.5 \%$ & \\
\hline & & $15 \%$ & \multicolumn{2}{|c|}{$72 \%$} & \multicolumn{2}{|c|}{$11 \%$} & $2 \%$ \\
\hline Tadoussac & W $88 / 89$ & 8 & 23 & 27 & 9 & 1 & 4 \\
\hline & W 91 & 18 & 13 & 19 & 10 & 2 & 4 \\
\hline \multirow[t]{2}{*}{ Total } & & 26 & 36 & 46 & 19 & 3 & 8 \\
\hline & & $19 \%$ & \multicolumn{2}{|c|}{$59 \%$} & \multicolumn{2}{|c|}{$16 \%$} & $6 \%$ \\
\hline Gr. Jardins & S 88 & 3 & 1 & - & 14 & - & - \\
\hline St. Siméon & S 85 & 2 & - & - & 3 & 1 & - \\
\hline \multirow[t]{3}{*}{ Total } & & 5 & 1 & - & 17 & 1 & - \\
\hline & & & & $0 \%$ & & $55 \%$ & \\
\hline & & $21 \%$ & \multicolumn{2}{|c|}{$4 \%$} & \multicolumn{2}{|c|}{$75 \%$} & $0 \%$ \\
\hline \multirow[t]{2}{*}{ St. Siméon } & W 88/89 & 5 & 8 & 5 & 13 & 1 & 4 \\
\hline & W 91 & 4 & 4 & 5 & 4 & 2 & 1 \\
\hline \multicolumn{2}{|c|}{$\begin{array}{l}\text { Rouyn-Noran- W } 90 \\
\text { da }\end{array}$} & 9 & 4 & 3 & 39 & - & - \\
\hline \multirow[t]{2}{*}{ Total } & & 18 & 16 & 13 & 56 & $\begin{array}{c}3 \\
5 \%\end{array}$ & 5 \\
\hline & & $16 \%$ & \multicolumn{2}{|c|}{$26 \%$} & \multicolumn{2}{|c|}{$53 \%$} & $5 \%$ \\
\hline
\end{tabular}

Iㅇ, I 9 우 one or several intermorphic queens; Gㅇ, G우 one or several gynomorphic queens; IG $\bigcirc$ intermorphic and gynomorphic queens. The percentages of colonies with multiple intermorphic queens and multiple gynomorphic queens are based on the number of colonies with intermorphic or gynomorphic queens. Other percentages are based on the total number of colonies of Leptothorax sp. A collected. $\mathrm{S}=$ summer (June to September), $\mathrm{W}=$ winter (October to May)
Mixed colonies, i.e., nests with inseminated gynomorphs and intermorphs, were surprisingly rare (Table 3 ).

Colonies with several inseminated intermorphs were more frequent in winter samples than in summer (KStest, $P<0.001$ ), but the frequency of colonies with multiple inseminated gynomorphs did not vary with the season (KS-test, $P>0.05$; Table 3 ).

In the majority of nests of Leptothorax sp. A, only one queen was reproductive. Additional queens, though inseminated, did not lay eggs (functional monogyny). Occasionally, truly polygynous nests of Leptothorax sp. A were found. In 8 colonies of a total of $85(9 \%)$, in which all queens were dissected, two egg-laying queens were present. Polygyny appeared more common in areas with a high percentage of gynomorphic queens ( 5 of 12 dissected colonies from Lac Arthabaska and St. Siméon, 42\%) than in areas with predominantly intermorphic queens ( 2 of 65 dissected colonies from Tadoussac, 3\%).

\section{Colony demography: worker numbers}

The average number of workers in colonies of Leptothorax sp. A varied seasonally (Fig. 2, Table 4): in the Tadoussac population, summer colonies with intermorphic queens were distinctly smaller than winter nests, and similarly, colonies with gynomorphic queens from St. Siméon were smaller in summer. Summer colonies with gynomorphic queens from Tadoussac were smaller than winter nests, but the difference was not statistically significant. Worker numbers appeared slightly higher also in winter nests of $L$. canadensis, but there were not enough data to substantiate fluctuations of colony structure.

\section{Mating behavior}

Sexuals of Leptothorax sp. A and L. canadensis eclose in July and mate probably in August (mating was not observed in the field, but see Francoeur 1986; Eidmann 1933). Female sexuals of both species show sexual calling

Table 4. Worker number in summer and winter nests of Leptothorax sp. A and L. canadensis

\begin{tabular}{|c|c|c|c|c|c|c|c|}
\hline & \multicolumn{3}{|c|}{ Summer } & \multicolumn{4}{|c|}{ Winter } \\
\hline & $n$ & $\bar{x}$ & SD & $n$ & $\bar{x}$ & SD & $P$ \\
\hline \multicolumn{8}{|c|}{ Leptothorax sp. A } \\
\hline $\begin{array}{l}\text { Tadoussac I } \\
\text { Tadoussac G } \\
\text { St. Siméon G }\end{array}$ & $\begin{array}{l}60 \\
11 \\
14\end{array}$ & $\begin{array}{l}21.1 \\
27.7 \\
24.3\end{array}$ & $\begin{array}{l}20.4 \\
21.6 \\
20.4\end{array}$ & $\begin{array}{l}73 \\
19 \\
16\end{array}$ & $\begin{array}{l}45.2 \\
54.3 \\
55.0\end{array}$ & $\begin{array}{l}30.8 \\
31.6 \\
31.2\end{array}$ & $\begin{array}{l}<0.01 \\
>0.05 \\
<0.05\end{array}$ \\
\hline \multicolumn{8}{|l|}{ L. canadensis } \\
\hline $\begin{array}{l}\text { Tadoussac } \\
\text { St. Siméon }\end{array}$ & 8 & 32.3 & 23.2 & $\begin{array}{l}20 \\
15\end{array}$ & $\begin{array}{l}42.8 \\
47.5\end{array}$ & $\begin{array}{l}29.5 \\
34.2\end{array}$ & $>0.05$ \\
\hline
\end{tabular}

Differences of frequency distributions of worker numbers were tested using the KS-test. Worker numbers do not differ between colonies with intermorphic (I) and gynomorphic (G) queens in summer and winter in the Tadoussac population (KS-test, $P>0.05$ ) 


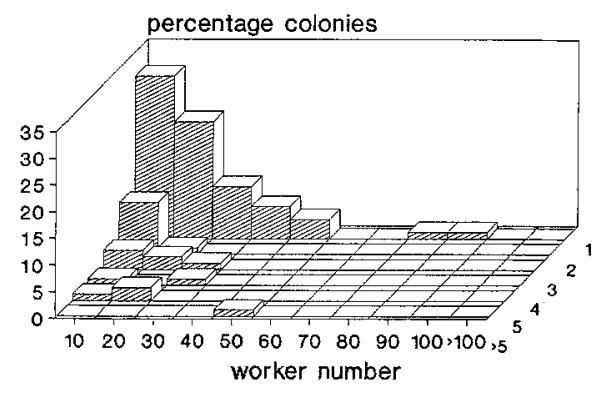

82 colonies

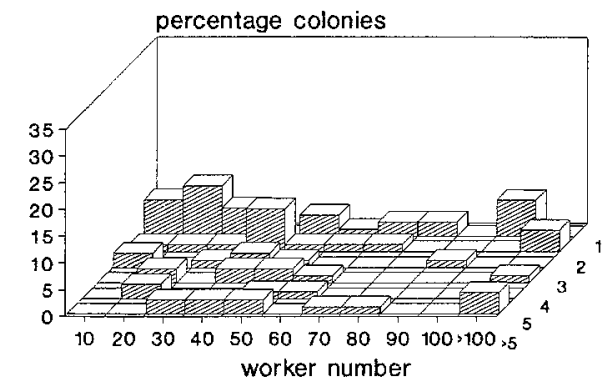

74 colonies

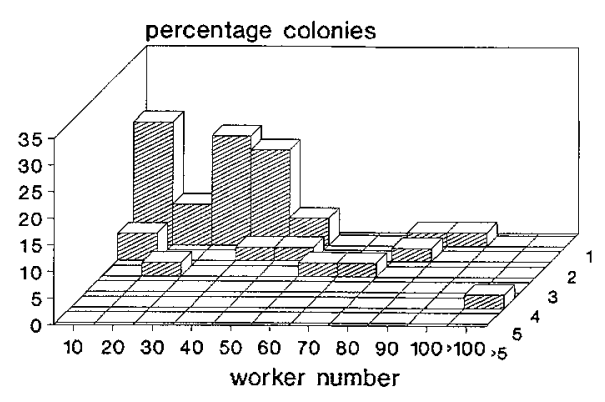

39 colonies

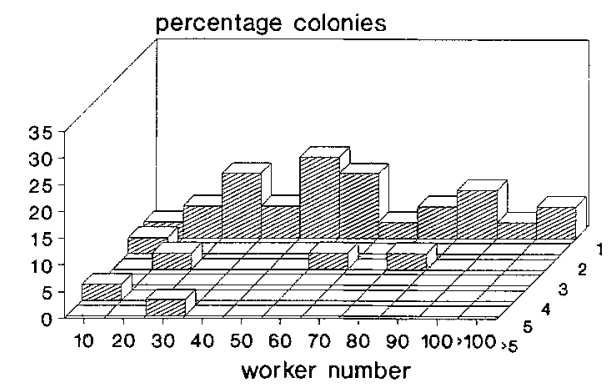

33 colonies
Fig. 2. Size distribution of colonies of Leptothorax sp. A with intermorphic (left) and gynomorphic queens (right) collected in summer (top) and winter (bottom) from various populations in Québec. Queen numbers ( 1 to $>5)$ are given on the third axis behavior at different times of the day. Virgin queens of L. canadensis are active directly after sunrise, while those of Leptothorax sp. A start calling 3-4 h later. In the laboratory, winged virgin queens of both species exhibited flight activity before beginning sexual calling and thus migrated from the maternal nest for up to $5 \mathrm{~m}$ and more. Virgin queens of $L$. canadensis mated less readily in the laboratory and flew more extensively than winged virgin queens of Leptothorax sp. A. It is likely that under natural conditions mating takes place only after prolonged ground swarming. Mating flights of large black Leptothorax (s.str.), probably $L$. canadensis, have indeed been observed in the field (T.M. Alloway, cited by Francoeur 1986). Some virgin intermorphs of Leptothorax $\mathrm{sp}$. A, on the other hand, started sexual calling in the immediate neighborhood of their maternal nest, whereas others moved about for more than half an hour before finally assuming the calling posture. Some climbed up sticks and then "jumped down", resembling the "take off" of winged queens.

\section{Dispersal and colony founding}

Directly after mating, 41 intermorphic queens (from six colonies) and 43 gynomorphic queens (from eight colonies) of Leptothorax sp. A were put into arenas (about $25 \times 25 \mathrm{~cm}^{2}$ ) containing their maternal nests and additional empty nest sites. All intermorphs returned to their maternal nests within a few hours and remained there at least till the end of hibernation, though some temporarily left the nest. Aggressive interactions between adopted intermorphic queens and workers or the resident queen were not observed, neither did intermorphic queens start to develop their ovaries before hibernation.

In contrast, 13 of 43 young gynomorphic queens hibernated solitarily without returning to the nest. Of 27 additional gynomorphs (from three colonies) which were carefully placed in their maternal colonies after mating, 16 were attacked and finally killed by workers before hibernation. Dissection of 13 killed gynomorphic queens showed that their ovarioles were elongated and contained developed oocytes.

Five virgin queens of $L$. canadensis (from two colonies) which mated in the laboratory were readily accepted by their maternal colonies when put back into the nest entrance.

In the field, solitary founding queens of both species were rare. Only 5 of a total of 650 colonies of Leptothorax sp. A and 5 of 300 colonies of $L$. canadensis consisted of a single queen (in the case of Leptothorax sp. A, two gynomorphs and three intermorphs). It must be noted, however, that very small colonies are difficult to locate in the nesting material and are likely to be overlooked.

\section{Queen antagonism and budding}

As shown in detail elsewhere (Heinze and Smith 1990), intermorphic queens in colonies of Leptothorax sp. A engaged in aggressive interactions directly after hibernation, which resulted in the formation of hierarchies. In each colony, only the top-ranking queen began to lay eggs. Subordinate queens either remained in the nest without reproducing, emigrated, or were expelled by workers. In ten laboratory colonies, one or more queens left the nest without any preceding overt aggression.

No aggressive interactions among nestmate queens were observed in two colonies of Leptothorax canadensis during $15 \mathrm{~h}$ observation. However, as in Leptothorax $\mathrm{sp}$. A, some queens spontaneously emigrated from nests of $L$. canadensis in early spring.

When additional nest sites were provided, six colonies of Leptothorax sp. A with multiple inseminated queens 
split into two or more fragments, i.e, some queens, workers, and brood emigrated from the main colony and settled in the new nests. In four cases, no queen became fertile in addition to the original queen and the buds fused again during summer. In two colonies, however, the two fragments each had a fully reproductive queen approximately 6 weeks after fragmentation and did not reunite. The finding of very small colonies, consisting of a queen not yet reproducing and two to five workers in early summer suggests that budding occurs in the field.

In a number of preliminary experiments it was tested whether colony buds can possibly fuse again, as was observed in seasonally polydomous species of Leptothorax (Myrafant) (e.g., Alloway et al. 1982; Herbers 1986a, 1986b). However, workers from two colony buds that were reintroduced into their colonies of origin about 3 months after fragmentation were attacked by their former nestmates with mandible threats, biting, and violent antennation. Similarly, when the dominant queens were removed from three colonies and returned to them only after replacement queens had started to lay eggs, they were heavily attacked and finally killed by the workers. According to dissection results, winter colonies contained only one queen which had laid eggs (see above), suggesting also that colony buds do not merge.

\section{Discussion}

Queens of the two nearctic ant species Leptothorax canadensis and Leptothorax sp. A may either establish colonies independently after mating or seek adoption into a mature nest and found their own colonies by emigration or budding in spring. Dispersal strategies are strongly influenced by genetically mediated queen morphology in Leptothorax sp. A (Heinze and Buschinger 1989): winged virgin queens predominantly disperse, whereas the majority of wingless intermorphs mate near the maternal nest and return to it for hibernation.

The co-occurrence of alternative dispersal and colony founding strategies within a species is not uncommon among ants (e.g., Rosengren and Pamilo 1983; Hölldobler and Carlin 1985; Sundström 1990). Solitary colony founding in ants is typically characterized by high mortality and high colony failure rates. Dependent strategies - queen adoption and subsequent budding - are safer but prevent long-range dispersal and thus increase competition for nest sites in the neighborhood of the maternal nest or for reproductive rights within the colony (Rosengren and Pamilo 1983).

In most cases dispersing and remaining queens are morphologically indistinguishable and it is unknown how common the different behaviors are in the field. The correlation between genetically mediated morphology and mating and founding behaviors of Leptothorax sp. A queens allows us to estimate the frequency of the two strategies. Though random founder-effects, the occurrence of competitors for nest sites (e.g., Herbers 1989), depth and duration of snow cover, and other factors may also be important, morph frequency in populations of Leptothorax sp. A appears to be predominantly deter- mined by the density of available nest sites and the size of habitat patches. Leptothorax sp. A is a habitat specialist, which nests predominantly in areas with intermediate insolation. Large, light patches are common around bare, rocky outcrops, where they may cover several square meters and can carry dozens of colonies. The density of potential nest sites is high on these patches and short-range dispersal on foot, i.e., budding, may therefore be successful. Where these rocky hummocks are wind-exposed, isolated, and surrounded by areas uninhabitable to Leptothorax sp. A, intermorphic queens are extremely abundant (appr. $80 \%$ in Tadoussac, $90 \%$ in Matagami). The low frequency of gynomorphic queens in these habitats might be caused by strong selection against flight activity (winged queens might drift off into areas unsuitable for colony founding) or by net emigration of winged queens (i.e., more winged queens leave the patch than immigrate). Both factors appear to be important causes of the predominance of wingreduced forms in isolated populations of non-social insects (e.g., Harrison 1980; Den Boer 1990). Isolated patches, recently cleared by man or wildfire (see, e.g, Punttila et al. 1991 for the effect of forest fires on populations of boreal ants), will be colonized by winged queens of Leptothorax sp. A, some probably carrying sperm with the genetic information for wing reduction and thus spreading winglessness from patch to patch.

In extended coniferous forests and forest tundra, sites with the right insolation are homogeneously scattered over large areas but are comparatively small. They typically cannot carry more than a few colonies and may be several meters apart, too far to be easily reached by Leptothorax ants on foot. Gynomorphic queens predominate in these areas $(80-90 \%$ of all colonies collected at Lac Arthabaska, Mt. du Lac des Cygnes, and Mt. Monadnock contained gynomorphic queens): winged queens, which can search large areas, might be more successful in locating suitable nest sites.

The uniformly winged queens of the sympatric species Leptothorax canadensis appear to be less strongly affected by habitat heterogeneity, probably because they are not limited to partly shaded areas but nest both in sunny and in darker habitats. Hence, budding is possible for them in extended forests and dispersal flights are not selected against on wind-exposed rocky outcrops. The percentage of multiple-queen colonies is indeed similar in different habitat types (Table 2).

Queen adoption in ants is mostly linked with secondary polygyny (Hölldobler and Wilson 1977, 1990; Keller 1991). Rather than leaving the nest for budding, some queens stay and reproduce in the maternal colony. Colonies of Leptothorax canadensis which adopt young mated queens thus easily become polygynous. In Leptothorax $\mathrm{sp}$. A, on the other hand, queens engage in aggressive interactions and establish dominance hierarchies, in which only the top-ranking queen reproduces (Heinze and Smith 1990). Fighting among the queens started in early spring, when the ovaries of all queens were similarly undeveloped. Aggressive interactions were rare directly after adoption in late summer. Newly adopted intermorphic queens apparently submitted to the fertile resident 
queen and did not start to reproduce. In contrast, more than half of all gynomorphic queens that were experimentally reintroduced into their maternal nests began to develop oocytes and were attacked and expelled or killed by workers.

Different attitudes of workers towards newly adopted queens of different genotype has also been observed in a polygynous population of the fire ant, Solenopsis invicta. Queens carrying a certain allelic variant of the enzyme phosphoglucomutase-3 were selectively destroyed by workers (Ross 1992; Keller and Ross 1993). Queens of the attacked genotype were heavier and laid significantly more eggs than queens of other genotypes. Similarly, gynomorphic queens of Leptothorax sp. A are typically larger and heavier than intermorphic queens (Heinze and Buschinger 1987) and thus might be better equipped for solitary founding. Whether they begin to grow oocytes shortly after mating as an adaptation to solitary colony founding or whether they are less susceptible than intermorphic queens to inhibitory signals of a fertile resident queen is as yet not known.

Long range dispersal and lower acceptability of gynomorphic queens of Leptothorax sp. A obviously affect the social organization of colonies in this species. Colonies tend to have a single queen in populations with a high percentage of gynomorphic queens, but several competing queens in populations with a high percentage of intermorphic queens. Due to functional monogyny, in both cases colonies have only one egg-laying queen. However, newly adopted queens may successfully challenge the position of the dominant queen, and at least in a related species, Leptothorax gredleri, queen supersession is quite common, significantly decreasing the relatedness among nestmates (Heinze et al. 1992b). Preliminary allozyme analyses suggest that the relatedness among workers in nests from a population rich in gynomorphic queens is close to the value expected for monogyny and single mating, whereas the estimate is lower in populations with many intermorphic queens (unpublished results).

Acknowledgements. Studies were supported by the Studienstiftung des deutschen Volkes, a NATO Science fellowship, a grant of the Deutsche Forschungsgemeinschaft (He 1623/2-1), and the DFG Leibniz-award to Bert Hölldobler. I thank E.O. Wilson and B. Hölldobler for their hospitality during a postdoctoral fellowship at Harvard University, A.F.G. Bourke, A. Buschinger, K. Fiedler, B. Hölldobler, L. Keller, C. Peeters, K. Sommer, and an unknown referee for helpful discussions and/or comments on earlier drafts of the manuscript. A. Buschinger, S.P. Cover, S. Kauffmann, and L. Tennant helped to collect colonies in the field.

\section{References}

Alloway TM, Buschinger A, Talbot M, Stuart R, Thomas C (1982) Polygyny and polydomy in three North American species of the ant genus Leptothorax Mayr (Hymenoptera: Formicidae). Psyche 89:249-274

Aukema B (1991) Fecundity in relation to wing-morph of three closely related species of the melanocephalus group of the genus Calathus (Coleoptera: Carabidae). Oecologia 87:118-126

Bolton B (1986) Apterous females and shift of dispersal strategy in the Monomorium salomonis-group (Hymenoptera: Formicidae). J Nat Hist 20:267-272
Briese DT (1983) Different modes of reproductive behaviour (including a description of colony fission) in a species of Chelaner (Hymenoptera: Formicidae). Insectes Soc 30:308-316

Buschinger A (1974) Experimente und Beobachtungen zur Gründung und Entwicklung neuer Sozietäten der sklavenhaltenden Ameise Harpagoxenus sublaevis (Nyl.). Insectes Soc 21 :381-406

Buschinger A (1978) Genetisch bedingte Entstehung geflügelter Weibchen bei der sklavenhaltenden Ameise Harpagoxenus sublaevis (Nyl.) (Hym., Form.). Insectes Soc 25: 163-172

Buschinger A, Alloway TM (1978) Caste polymorphism in Harpagoxenus canadensis M.R. Smith (Hym., Formicidae). Insectes Soc 25: 339-350

Buschinger A, Heinze J (1992) Polymorphism of female reproductives in ants. In: Billen $\mathrm{J}$ (ed) Biology and evolution of social insects. Leuven University Press, Leuven, pp 11-23

Buschinger A, Winter U (1976) Funktionelle Monogynie bei der Gastameise Formicoxenus nitidulus (Nyl.) (Hym., Form.). Insectes Soc 23:549-558

Den Boer PJ (1990) Density limits and survival of local populations in 64 carabid species with different powers of dispersal. J Evol Biol 3: $19-48$

Eidmann H (1933) Zur Kenntnis der Ameisenfauna von Südlabrador. Zool Anz 101:201-221

Francoeur A (1986) Deux nouvelles fourmis néarctiques: Leptothorax retractus et $L$. sphagnicolus (Formicidae, Hymenoptera). Can Entomol 118:1151-1164

Francoeur A, Loiselle R, Buschinger A (1985) Biosystématique de la tribu Leptothoracini (Formicidae, Hymenoptera). 1. Le genre Formicoxenus dans la région holarctique. Nat Can 112: 343-403

Harrison RG (1980) Dispersal polymorphism in insects. Annu Rev Ecol Syst 11:95-118

Heinze J (1989a) Alternative dispersal strategies in a North American ant. Naturwissenschaften 76:477-478

Heinze J (1989b) A biochemical approach toward the systematics of the Leptothorax "muscorum" group in North America (Hymenoptera: Formicidae). Biochem Syst Ecol 17:595-601

Heinze J, Buschinger A (1987) Queen polymorphism in a nonparasitic Leptothorax species (Hymenoptera, Formicidae). Insectes Soc 34:28-43

Heinze J, Buschinger A (1988a) Polygyny and functional monogyny in Leptothorax ants (Hymenoptera: Formicidae). Psyche $95: 309-325$

Heinze J, Buschinger A (1988b) Electrophoretic variability of esterases in the ant-tribe Leptothoracini. Biochem Syst Ecol $16: 217-221$

Heinze J, Buschinger A (1989) Queen-polymorphism in Leptothorax spec. A: its genetic and ecological background (Hymenoptera: Formicidae). Insectes Soc 36:139-155

Heinze J, Smith TA (1990) Dominance and fertility in a functionally monogynous ant. Behav Ecol Sociobiol 27:1-10

Heinze J, Hölldobler B, Cover SP (1992a) Queen polymorphism in the North American harvester ant, Ephebomyrmex imberbiculus. Insectes Soc 39:267-273

Heinze J, Lipski N, Hölldobler B (1992b) Reproductive competition in colonies of the ant Leptothorax gredleri. Ethology 90: 265-278

Herbers JM (1986a) Ecological genetics of queen number in Leptothorax longispinosus (Hymenoptera: Formicidae). Entomol Gen 111:119-123

Herbers JM (1986b) Nest site limitation and facultative polygyny in the ant Leptothorax longispinosus. Behav Ecol Sociobiol $19: 115-122$

Herbers JM (1989) Community structure in north temperate ants: temporal and spatial variation. Oecologia 81:201-211

Hölldobler B, Bartz SH (1985) Sociobiology of reproduction in ants. In: Hölldobler B, Lindauer M (eds) Experimental behavioral ecology and sociobiology. Sinauer, Sunderland, pp 237-257

Hölldobler B, Carlin NF (1985) Colony founding, queen dominance and oligogyny in the Australian meat ant Iridomyrmex purpureus. Behav Ecol Sociobiol 18:45-58 
Hölldobler B, Wilson EO (1977) The number of queens: an important trait in ant evolution. Naturwissenschaften $64: 8-15$

Hölldobler B, Wilson EO (1990) The ants. Harvard University Press, Cambridge

Keller L (1991) Queen number, mode of colony founding, and queen reproductive success in ants (Hymenoptera Formicidae). Ethol Ecol Evol 3:307-316

Keller L, Ross KG (1993) Phenotypic basis of reproductive success in a social insect: genetic and social determinants. Science 260: $1107-1110$

Loiselle R, Francoeur A (1988) Régression du dimorphisme sexuel dans le genre Formicoxenus et polymorphisme comparé des sexes dans la famille des Formicidae (Hymenoptera). Nat Can $115: 367-378$

Loiselle R, Francoeur A, Fischer K, Buschinger A (1990) Variations and taxonomic significance of the chromosome numbers in the nearctic species of the genus Leptothorax (s.s.) (Formicidae: Hymenoptera). Caryologia 43:321-334

Peeters C (1991) Ergatoid queens and intercastes in ants: two distinct adult forms which look morphologically intermediate between workers and winged queens. Insectes Soc 38:1-15

Punttila P, Haila Y, Pajunen T, Tukia H (1991) Colonisation of clearcut forests by ants in the southern Finnish taiga: a quantitative survey. Oikos $61: 250-262$

Roff DA (1980) The evolution of wing dimorphism in insects. Evolution 40: 1009-1020

Roff DA, Fairbairn DJ (1991) Wing dimorphism and the evolution of migratory polymorphisms among the insecta. Am Zool $31: 243-251$
Rosengren R, Pamilo P (1983) The evolution of polygyny and polydomy in mound-building Formica ants. Acta Entomol Fenn 42:65-77

Ross KG (1992) Strong selection on a gene that influences reproductive competition in a social insect. Nature 355:347-349

Sachs L (1992) Angewandte Statistik, 7th edn. Springer, Berlin

Sokal RR, Rohlf FJ (1981) Biometry, 2nd edn. Freeman, New York

Sundström L (1990) Monogyny or polygyny - a result of different dispersal tactics in red wood ants (Formica; Hymenoptera). In: Veeresh GK, Mallik CA, Viraktamath CA (eds) Social insects and the environment. Oxford \& IBH, New Delhi, pp 245-246

Tinaut A, Heinze $J$ (1992) Wing reduction in ant queens from arid habitats. Naturwissenschaften 79:84-85

Varvio-Aho S-L, Järvinen O, Vepsäläinen K (1978) Enzyme gene variation in three species of water-striders (Gerris) (Heteroptera, Gerridae). Ann Entomol Fenn 44:87-94

Villet MH (1989) A syndrome leading to ergatoid queens in ponerine ants (Hymenoptera: Formicidae). J Nat Hist 23: $825-832$

Villet MH (1991) Colony foundation in Plectroctena mandibularis F. Smith, and the evolution of ergatoid queens in Plectroctena (Hymenoptera: Formicidae). J Nat Hist 25:979-983

Wagner DL, Liebherr JK (1992) Flightlessness in insects. Trends Ecol Evol 7:216-220

Zera AJ, Rankin MA (1989) Wing dimorphism in Gryllus rubens: genetic basis of morph determination and fertility differences between morphs. Oecologia 80:249-255 